\title{
Evolution of microstructure in flyash-containing porcelain body on heating at different temperatures
}

\author{
KAUSIK DANA and SWAPAN KUMAR DAS* \\ Central Glass and Ceramic Research Institute, Kolkata 700 032, India
}

MS received 24 November 2003; revised 7 February 2004

\begin{abstract}
. $15 \mathrm{wt} \%$ flyash (a calcined byproduct of thermal power plant) was incorporated in a normal triaxial kaolin-quartz-feldspar system by replacing equivalent amount of quartz. The differences in microstructural evolution on heating the compact mass of both normal and flyash-containing porcelain at different temperatures $\left(1150-1300^{\circ} \mathrm{C}\right)$ were examined using scanning electron microscopy (SEM) operating in secondary electron image (SEI) mode. Microstructure of normal porcelain did not show the presence of mullite and quartz grains at $1200^{\circ} \mathrm{C}$ and the viscosity of silica-rich glass restricted the growth of mullite crystals at $1250^{\circ} \mathrm{C}$. Flyash porcelain, on the other hand, shows the presence of primary mullite aggregates in the clay relict and a significant growth of mullite crystals in a low viscosity glassy matrix at $1200^{\circ} \mathrm{C}$ itself. At $1300^{\circ} \mathrm{C}$, both the bodies show a larger region of more elongated $(>1 \mu \mathrm{m})$ secondary mullite along with clusters of smaller sized primary mullite $(<1 \mu \mathrm{m})$. Small primary mullite crystals in the clay relict can be distinguished from elongated secondary mullite crystals in the feldspar relict in their size. Primary mullite aggregates remain stable also at higher temperatures. XRD studies were carried out for quantitative estimation of quartz, mullite and glass, which supported the SEM observations. An attempt was also made to correlate their mechanical strength with the constituent phases.
\end{abstract}

Keywords. Microstructure; phases; porcelain; flyash.

\section{Introduction}

The evolution of microstructure and phase transformation of standard triaxial porcelain bodies (clay-quartz-feldspar) in relation to heating temperatures have been studied in great detail by many researchers (Klein 1916-17; Lundin 1964; Schuller 1964, 1982; Lee and Rainforth 1994; Carty and Senapati 1998; Iqbal and Lee 1999, 2000; Ece and Nakagawa 2002; Braganca and Bergmann 2003). At $550-600^{\circ} \mathrm{C}$, the kaolinitic clay dehydroxylates to form metakaolin followed by its transformation to a spinel type structure and amorphous silica at $950-1000^{\circ} \mathrm{C}$. Above $1100^{\circ} \mathrm{C}$, the spinel transforms to primary mullite and silica and at above $1200^{\circ} \mathrm{C}$ secondary mullite forms by the reaction of clay relicts with feldspar relicts (Iqbal and Lee 1999, 2000). Scaly type of mullite (aggregate of small crystals, $<0.5 \mu \mathrm{m}$ ) originated from clay referred to as primary mullite and needle shaped mullite $(>1 \mu \mathrm{m})$ from feldspar melt referred to as secondary mullite. Mullite crystals forming in presence of feldspar melt are acicular and those forming in the clay relicts are uniform and uniaxed (Metcalfe and Sant 1975). Primary mullite gradually transforms to secondary mullite by crystallization. Quartz used as filler materials in porcelain composition starts

\footnotetext{
*Author for correspondence
}

dissolving at above $1250^{\circ} \mathrm{C}$ and forms silica rich amorphous solution rims around quartz grains. The dissolution rate of quartz depends on its size (Rado 1971). Fine quartz grains $(<20 \mu \mathrm{m})$ dissolve very rapidly. With increase in heating temperature, quartz and secondary mullite partly dissolve in the glass melt, whereas aggregates of scaly primary mullite remain stable at higher temperature (Schuller 1964). At around $1300^{\circ} \mathrm{C}$, quartz based porcelain body mainly consists of quartz, mullite and glass. Larger quartz grains $(>20 \mu \mathrm{m})$ completely dissolve at $1350^{\circ} \mathrm{C}$ and a porcelain body at temperature $>1400^{\circ} \mathrm{C}$ consists almost entirely of mullite and glass with little quartz. Cracks are commonly observed around quartz grains in standard porcelain microstructures because of the large thermal expansion mismatch between glassy and crystalline phases in the temperature range $20-750^{\circ} \mathrm{C}$ (Mattyasovsky 1957 ; Lundin 1964). It was reported that presence of higher amount of fine grained quartz increases the strength in a porcelain body (Wiedmann 1959) while others claimed that low quartz content provides higher strength (Palatzky and Tummler 1958; Weyl 1959). A dense microstructure of $1250^{\circ} \mathrm{C}$ heated flyash containing porcelain body ( $25 \mathrm{wt} \%$ clay was replaced by flyash in a normal porcelain composition) was characterized by a very small number of pores, interlocked quartz and mullite crystals embedded in a glassy matrix (Kumar et al 2001). The microstructure and phase evolution of flyash-containing 
porcelain body on heating at different temperatures are not adequately reported in the literature, particularly when quartz is substituted by flyash.

The purpose of the present study is to replace $15 \mathrm{wt} \%$ of quartz by flyash in a standard porcelain composition and investigate their differences in microstructural and phase evolution with standard porcelain body at different firing temperatures $\left(1150-1300^{\circ} \mathrm{C}\right)$. The microstructural observation was supported by XRD results. Finally, effect of such changes on the mechanical strength has also been discussed in this paper.

\section{Experimental}

All raw materials were collected from Indian sources (Clay from Rajmahal, Bihar; feldspar and quartz, Ranchi, Bihar; flyash from NALCO thermal power station, Orissa) and chemically analysed. Gravimetric method was utilized to determine $\mathrm{SiO}_{2}$ and $\mathrm{Al}_{2} \mathrm{O}_{3}$ whereas $\mathrm{Fe}_{2} \mathrm{O}_{3}, \mathrm{CaO}$ and $\mathrm{MgO}$ were estimated volumetrically (Hillebrand and Lundell 1953). Alkalies were determined by flame photometry.

Two different porcelain samples were prepared as per the batch composition provided in table 1 . Green samples $(60 \times 14 \times 5 \mathrm{~mm})$ were prepared as per the flow sheet given in figure 1 . All the compacted samples after proper drying were heated at $1150,1200,1250$ and $1300^{\circ} \mathrm{C}$ for a soaking period of $120 \mathrm{~min}$ in an electrically operated laboratory furnace using on/off control system. A constant heating rate of $8^{\circ} \mathrm{C} / \mathrm{min}$ was maintained during firing. Flexural strength (three-point bending) of the fired samples was determined by universal testing machine

Table 1. Batch compositions (wt\%).

\begin{tabular}{lcccc}
\hline Batches & Kaolinitic clay & Feldspar & Quartz & Flyash \\
\hline NP & 45 & 30 & 25 & 0 \\
FP & 45 & 30 & 10 & 15 \\
\hline
\end{tabular}

(INSTRON 5500R). The results reported here is the average of six samples. For scanning electron microscopic study, samples were polished to $1 \mu \mathrm{m}$ finish with diamond paste after initial grinding with $\mathrm{SiC}$ powder and water. The polished surfaces of such samples were etched for $3 \mathrm{~min}$ in $5 \% \mathrm{HF}$ solution at room temperature $\left(35^{\circ} \mathrm{C}\right)$, washed in water and acetone followed by gold sputter coating (Edwards, Scancoat). SEM (LEO 430i) was used for obtaining secondary electron images (SEI) of etched surfaces. X-ray diffraction studies were carried out with powder (-200 mesh BS sieve) of each of the samples. Philips 'X-Pert Pro' diffraction unit, attached with secondary monochromator, automatic divergence slit and nickel filter, was used to get monochromatic $\mathrm{Cu}-\mathrm{K} \alpha$ radiation. The instrument was run at step scan mode with step size $(0.02)$ and $8 \mathrm{~s}$ time per step, within $2 \theta$ angle $5^{\circ}$ to $75^{\circ}$. The collected data was refined using Profit software. XPert plus and Quasor software based on Rietveld were used to calculate the percentage of mullite and quartz, where standard quartz and mullite were used as reference material. The weight percent of glass was estimated by substracting sum of the wt $\%$ of quartz and mullite from 100. For reliability of data, each sample was scanned several times. The fitted curve matched well with the raw data and 'goodness of fit' varied from 2.5-4 among different samples.

\section{Results and discussion}

\subsection{Raw materials}

The results of chemical analysis of all raw materials are given in table 2 . It may be seen that clay, quartz and feldspar are of normal type generally used to produce such type of porcelain bodies. Flyash contains some other oxides in the higher level such as $\mathrm{Fe}_{2} \mathrm{O}_{3}$ (4.00 wt $\left.\%\right)$, $\mathrm{TiO}_{2}$ $(2.92 \mathrm{wt} \%)$ and $\mathrm{CaO}(2.63 \mathrm{wt} \%)$. These oxides may play a significant role towards vitrification, phase transformation and growth of mullite crystals in the flyash-contain-

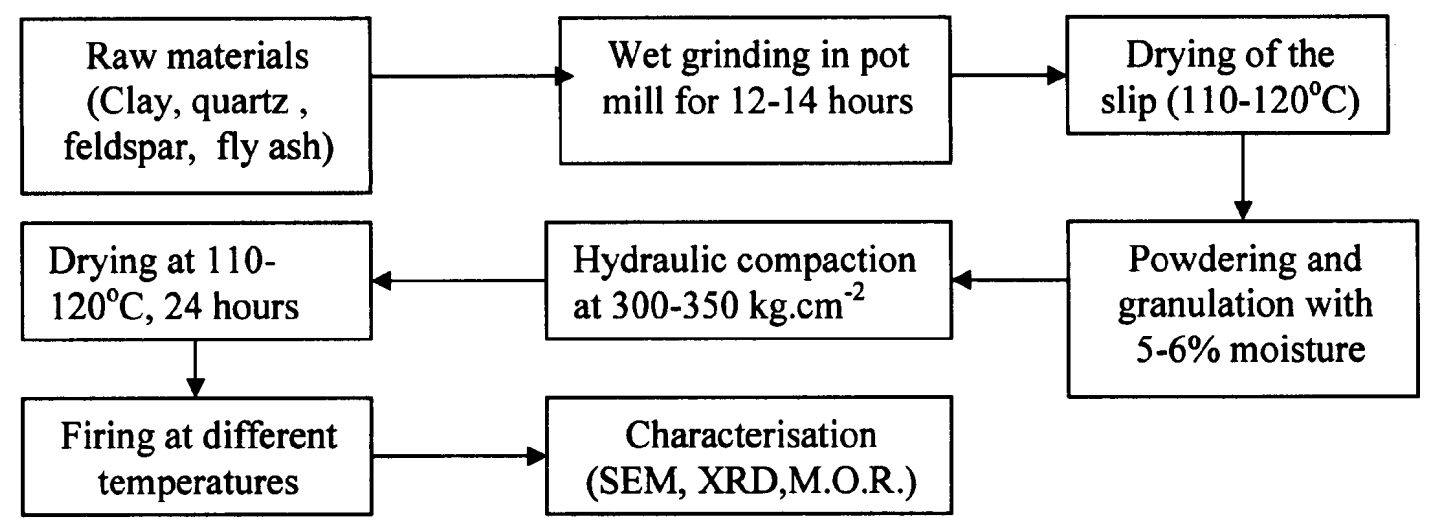

Figure 1. Flow sheet diagram for the preparation of samples. 
ing porcelain body as reported by other workers (Chaudhuri 1974; Johnson and Pask 1982) in their studies where addition of such oxides in a porcelain body and kaolin-alumina-silica mixture changes the properties.

Table 2. Chemical analysis of the raw materials.

\begin{tabular}{|c|c|c|c|c|}
\hline $\begin{array}{l}\text { Major } \\
\text { chemical } \\
\text { constituents } \\
\text { (wt } \%)\end{array}$ & $\begin{array}{l}\text { Kaolinitic } \\
\text { clay }\end{array}$ & Feldspar & Quartz & Flyash \\
\hline $\mathrm{SiO}_{2}$ & $45 \cdot 41$ & $66 \cdot 48$ & $98 \cdot 66$ & $59 \cdot 26$ \\
\hline $\mathrm{Al}_{2} \mathrm{O}_{3}$ & $34 \cdot 39$ & $17 \cdot 29$ & $0 \cdot 39$ & 27.97 \\
\hline $\mathrm{Fe}_{2} \mathrm{O}_{3}$ & $1 \cdot 13$ & 0.14 & 0.07 & 4.00 \\
\hline $\mathrm{TiO}_{2}$ & 0.89 & 0.02 & 0.01 & 2.92 \\
\hline $\mathrm{CaO}$ & 1.07 & $0 \cdot 31$ & $0 \cdot 10$ & 2.63 \\
\hline $\mathrm{MgO}$ & 0.76 & 0.03 & 0.02 & $0 \cdot 56$ \\
\hline $\mathrm{Na}_{2} \mathrm{O}$ & 0.87 & 2.94 & 0.09 & 0.54 \\
\hline $\mathrm{K}_{2} \mathrm{O}$ & 0.42 & 11.95 & $0 \cdot 12$ & 0.60 \\
\hline LOI & $14 \cdot 67$ & $0 \cdot 71$ & 0.37 & $1 \cdot 12$ \\
\hline
\end{tabular}
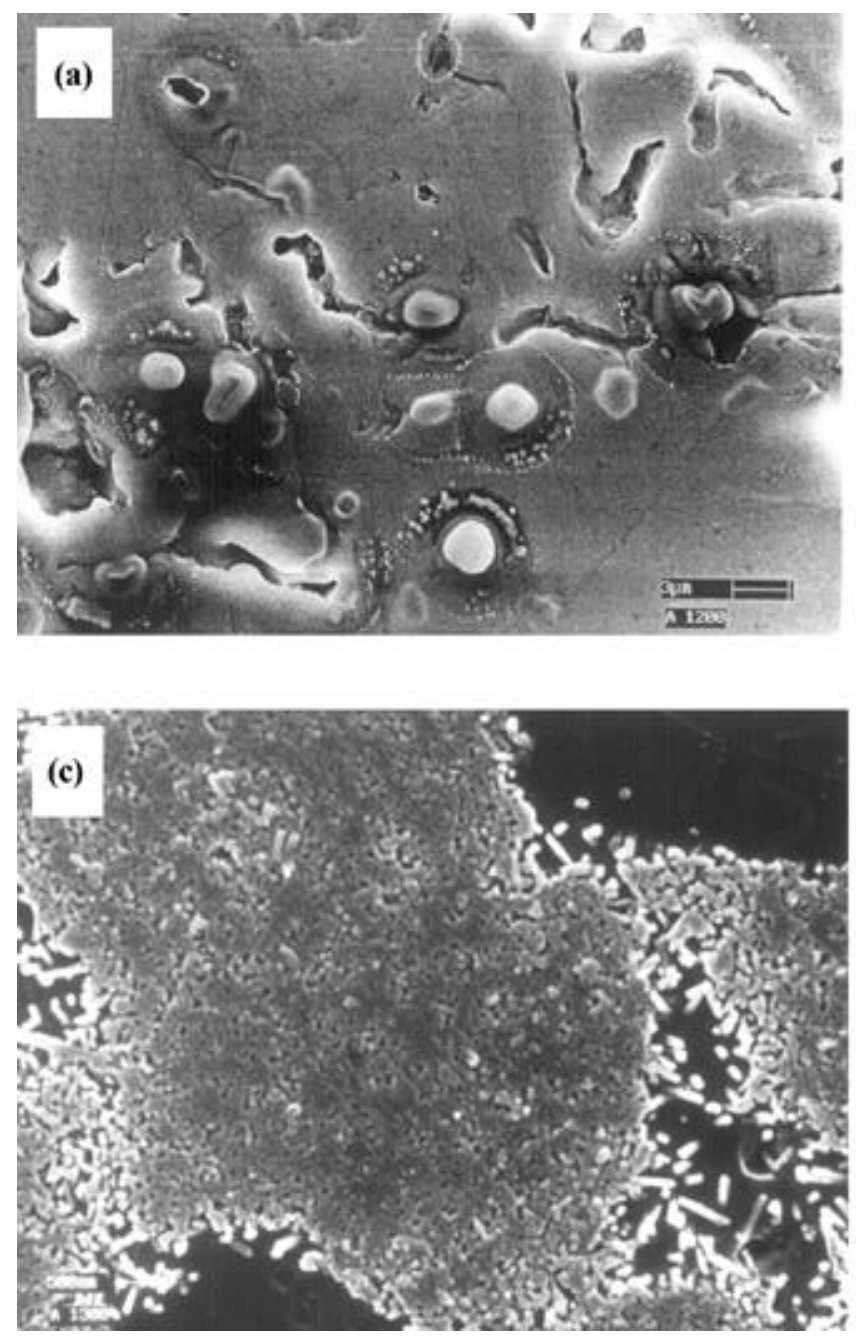

\subsection{Microstructure}

The SEM photomicrographs of some selected specimens of normal porcelain and flyash porcelain heated at different temperatures are shown in figures 2 and 3, respectively. Figure 2 a shows uneven texture, not enough dense glassy matrix in case of normal porcelain specimens (NP) at $1200^{\circ} \mathrm{C}$ indicating that firing temperature was not enough. Even though presence of quartz and mullite crystals was confirmed later by XRD study in this sample (table 3), they were not seen in SEM photomicrograph which may be due to incomplete etching of the sample. Presence of scaly type primary mullite aggregates and needle shaped secondary mullite crystals were observed in case of $1250^{\circ} \mathrm{C}$ heated specimens of NP (figure $2 b$ ). Quartz grains surrounded by rims of amorphous silica were also seen in figure $2 \mathrm{~b}$. The formation of such type of primary mullite from pure clay sample at around this temperature as reported by Chen and Tuan (2002) suggests that primary mullite in the present experimental body is also generated
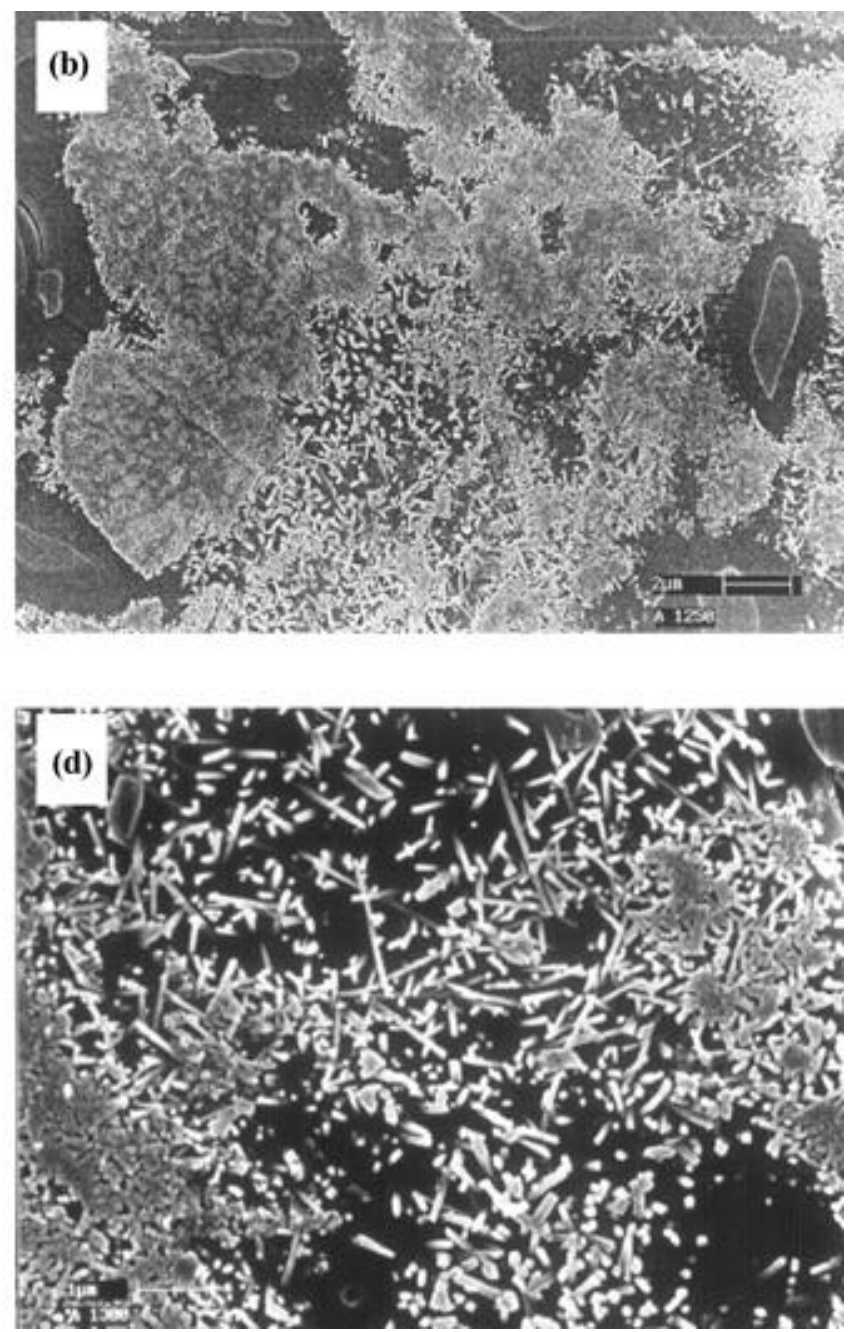

Figure 2. SEM photomicrographs of heated normal porcelain (NP) specimens (a) $1200^{\circ} \mathrm{C} ;(\mathbf{b}) 1250^{\circ} \mathrm{C} ;(\mathbf{c})$ and $(\mathbf{d}) 1300^{\circ} \mathrm{C}$. 
from clay relict. Iqbal and Lee (2000) also observed the formation of similar scaly type primary mullite in pure kaolin relicts at same temperature in their model porcelain. Secondary mullites seen in figure $2 b$ originated from feldspar penetrated clay relict. Figure 2c shows larger region of primary mullite in NP specimen at $1300^{\circ} \mathrm{C}$ confirming earlier observation (Schuller 1964) that aggregates of scaly primary mullite remains stable at higher temperature. Since primary mullite forms from clay relicts, it is believed to crystallize from a large portion of silica-rich glass. Due to high viscosity of silica-rich glass, growth of the mullite crystals is limited, hence mullite crystals $<1 \mu \mathrm{m}$ in size are observed in figure $2 \mathrm{c}$. Figure $2 \mathrm{~d}$ further shows larger region of more elongated secondary mullite crystals along with smaller sized primary mullite crystals within the same sample at the same temperature. The surrounding liquid in the feldspar penetrated clay relics is enriched in alkalies, hence it is more fluid which caused growth of nucleated secondary mullite crystals. Formation of more elongated morphology of secondary mullite crystals at the same temperature within
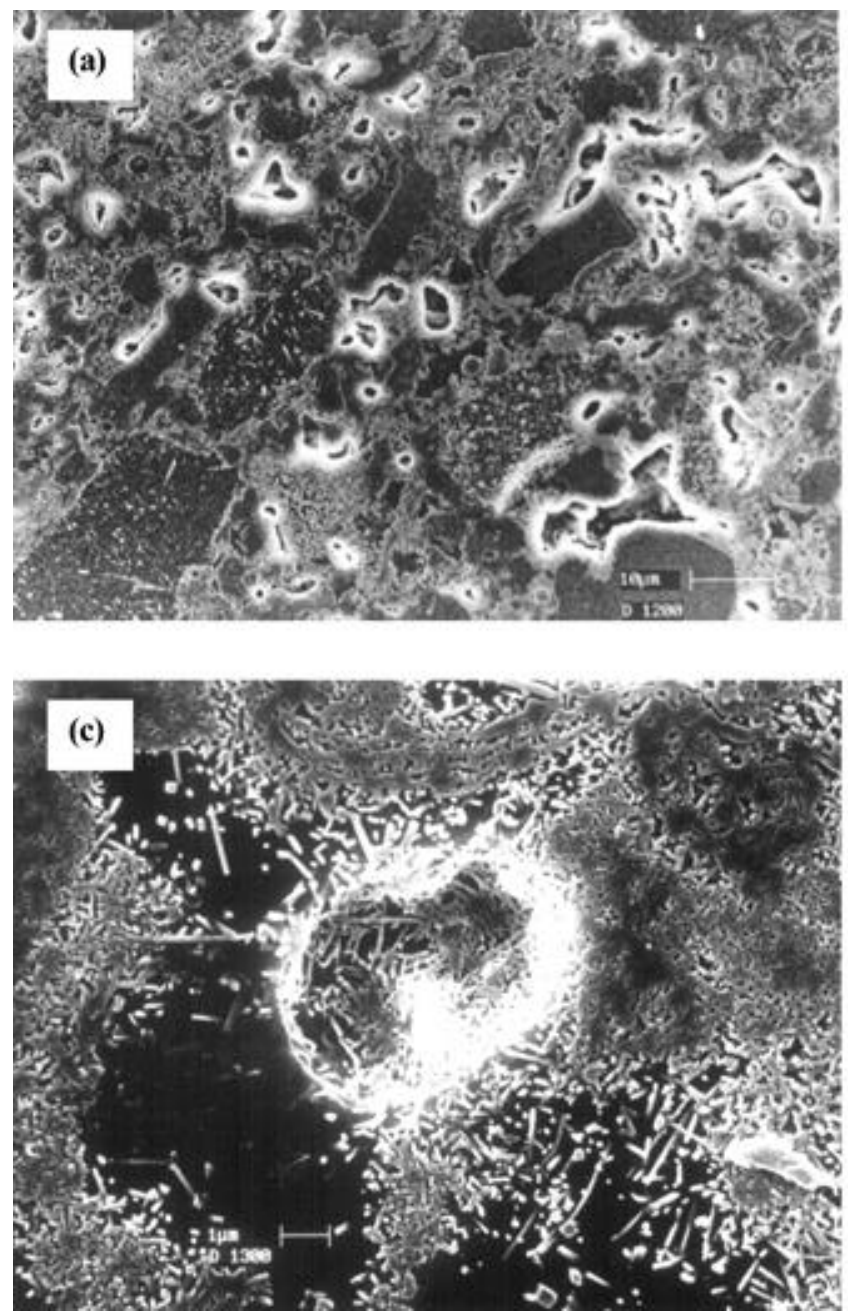

the same porcelain body is also reported (Iqbal and Lee 2000; Lee and Iqbal 2001).

SEM photomicrographs of flyash incorporated porcelain (FP) heated at different temperatures are shown in figures $3 \mathrm{a}-\mathrm{d}$. Compared to normal porcelain, distinct changes in morphology were observed in case of FP, particularly at $1200^{\circ} \mathrm{C}$. Replacement of $15 \mathrm{wt} \%$ quartz by the flyash and other oxides present in flyash made the glass more fluid at $1200^{\circ} \mathrm{C}$ and the etched surface clearly shows the presence of primary mullite in the clay relict, quartz grains and partially melted feldspar grains (figure $3 \mathrm{a}$ ). Due to high fluidity of the silica-less glass, the growth of mullite crystals were also observed in the $1200^{\circ} \mathrm{C}$ heated $\mathrm{FP}$ specimen (figure $3 \mathrm{~b}$ ). At $1300^{\circ} \mathrm{C}$, quartz grains were mostly dissolved in the glass and the microstructure mainly consisted of primary mullite aggregates and clusters of needle-shaped mullite crystals in the glassy matrix (figure $3 \mathrm{c}$ ). This observation is confirmed later from the findings of XRD study. In this case also, aggregates of primary mullite remain stable at higher temperatures. Figure $3 d$ shows the formation of more elongated morphology of
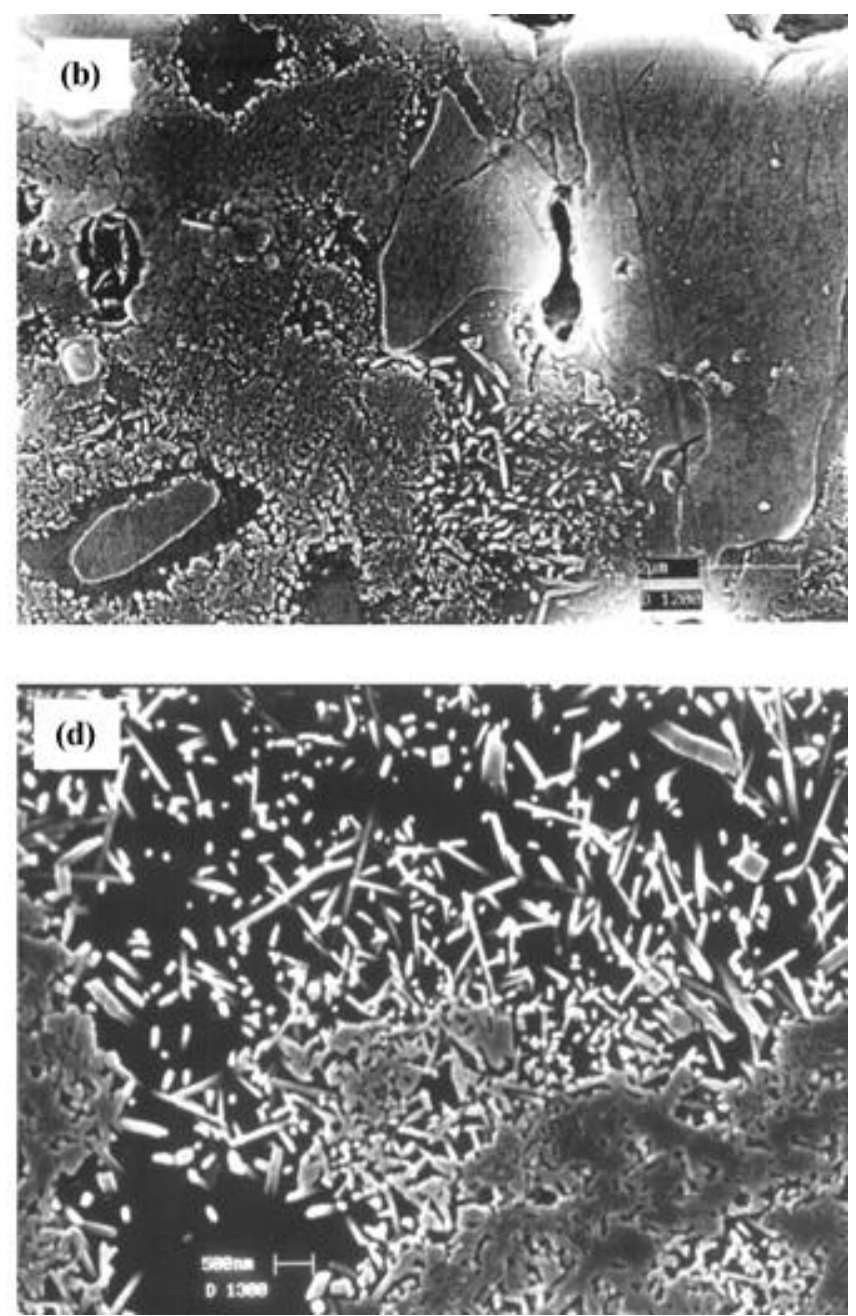

Figure 3. SEM photomicrographs of heated flyash porcelain (FP) specimens (a), (b) $1200^{\circ} \mathrm{C},(\mathbf{c})$ and (d) $1300^{\circ} \mathrm{C}$. 
Table 3. Quantitative presence of phases and MOR at different temperatures.

\begin{tabular}{|c|c|c|c|c|c|c|c|c|}
\hline \multirow{3}{*}{$\begin{array}{l}\text { Temperature } \\
\left({ }^{\circ} \mathrm{C}\right)\end{array}$} & \multicolumn{6}{|c|}{ Phases (wt\%) } & \multirow{2}{*}{\multicolumn{2}{|c|}{$\begin{array}{l}\text { Flexural strength } \\
\qquad(\mathrm{MPa})\end{array}$}} \\
\hline & \multicolumn{3}{|c|}{ NP } & \multicolumn{3}{|c|}{ FP } & & \\
\hline & $\mathrm{Q}$ & $\mathrm{M}$ & G & Q & $\mathrm{M}$ & $\mathrm{G}$ & $\mathrm{NP}$ & FP \\
\hline 1150 & 36 & $19 \cdot 5$ & $44 \cdot 5$ & 11 & $24 \cdot 3$ & $64 \cdot 7$ & 24.9 & $42 \cdot 1$ \\
\hline 1200 & 26 & $19 \cdot 5$ & $54 \cdot 5$ & 10 & 27 & 63 & $36 \cdot 5$ & $51 \cdot 1$ \\
\hline 1250 & $16 \cdot 5$ & $24 \cdot 3$ & $59 \cdot 3$ & 8 & 27 & 65 & $48 \cdot 1$ & $67 \cdot 7$ \\
\hline 1300 & 15 & 26 & $58 \cdot 7$ & 8 & $27 \cdot 5$ & $64 \cdot 5$ & $61 \cdot 1$ & $70 \cdot 5$ \\
\hline
\end{tabular}

M, mullite; Q, quartz and G, glass.
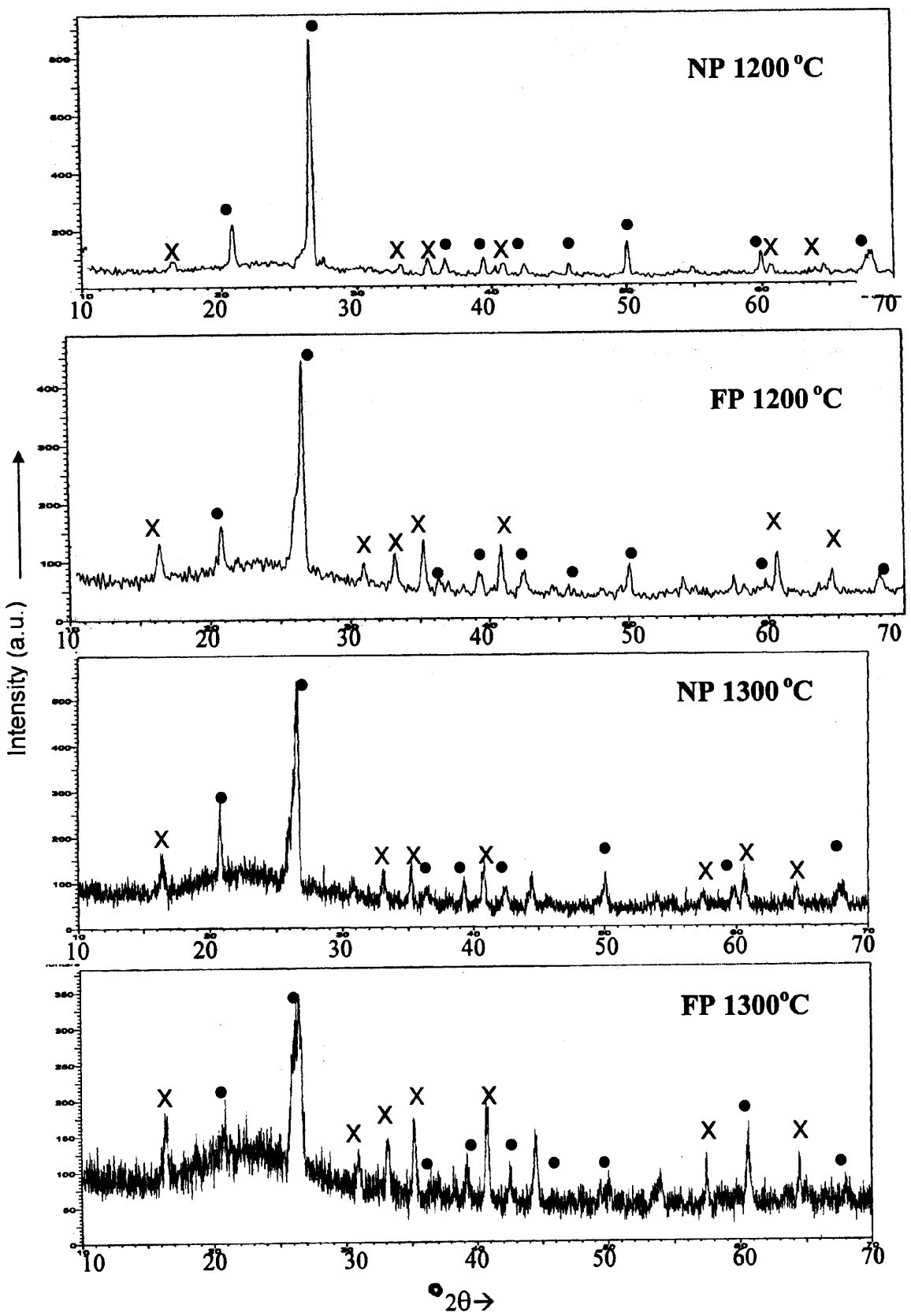

Figure 4. XRD pattern of representative specimens heated at different temperatures $(x=$ mullite; $\bullet=$ quartz). 
secondary mullite at the same temperature $\left(1300^{\circ} \mathrm{C}\right)$ within the same FP body. The morphology of the mullite crystals in NP and FP at $1300^{\circ} \mathrm{C}$ was almost similar. In contrast to present microstructure, some workers (Kumar et al 2001) reported different mullite textures at $1250^{\circ} \mathrm{C}$ in other type of flyash containing porcelain body where $25 \mathrm{wt} \%$ clay was substituted by flyash. However, presence of interlocked mullite and quartz crystals were observed by them. Primary mullite aggregates were seen to be less in this clay substituted flyash-porcelain body at $1250^{\circ} \mathrm{C}$.

\subsection{Phase analysis and flexural strength}

Table 3 provides the results of quantitative estimation of quartz, mullite and glass content in both the bodies at different temperatures along with their flexural strength values. It may be observed that in both the cases quartz content decreases with increase in temperature of heating due to its dissolution in the glass melt and it is more pronounced up to $1250^{\circ} \mathrm{C}$ beyond which the quartz dissolution almost stopped. Other workers (Lundin 1954, 1964) also observed that quartz dissolution in a porcelain body ceases after the glass melt is saturated with silica. Expectedly, FP body shows less quartz content and higher amount of mullite at all temperatures as $15 \mathrm{wt} \%$ quartz is substituted by flyash in this composition. Formation of more mullite in FP is attributed towards inherent presence of mullite in calcined flyash (Dana 2003). FP body contains higher amount of glass than NP at $1150^{\circ} \mathrm{C}$ itself and the glass formation is almost complete. The other oxides $\left(\mathrm{Fe}_{2} \mathrm{O}_{3}, \mathrm{CaO}, \mathrm{TiO}_{2}\right)$ present in flyash might have promoted glass formation in FP at this temperature. Presence of $13 \mathrm{wt} \%$ mullite, $24 \mathrm{wt} \%$ quartz and $63 \mathrm{wt} \%$ glass at $1250^{\circ} \mathrm{C}$ was reported (Kumar et al 2001) in a porcelain body where $15 \mathrm{wt} \%$ clay was substituted by flyash in a normal porcelain composition. In contrast to this amount of mullite and quartz in clay substituted flyash porcelain, it was found to be $27 \mathrm{wt} \%$ and $8 \mathrm{wt} \%$, respectively at $1250^{\circ} \mathrm{C}$ in the present investigation where quartz was substituted by flyash. Glass content in both the cases remains almost same. Presence of more clay and less quartz in the present composition is responsible for this observation. The XRD patterns of some representative specimens are exhibited in figure 4 . In spite of having more amount of glass in FP, the flexural strength of this body was found to be higher than NP at all the temperatures. This is due to strong reinforcement of the needle-shaped crystals of mullite in the glassy matrix which was confirmed by microstructural observations discussed earlier.

\section{Conclusions}

Flyash incorporated triaxial porcelain composition studied in the present investigation (substituting quartz) reaches its standard porcelain microstructure (consisting of quartz, mullite and glass) at lower temperature $\left(1200^{\circ} \mathrm{C}\right)$ compared to normal triaxial porcelain composition achi- eved at $1250^{\circ} \mathrm{C}$. Distinct differences in the formation of mullite crystals and their growth in a glassy matrix were observed between the two compositions particularly at 1200 and $1250^{\circ} \mathrm{C}$. At $1300^{\circ} \mathrm{C}$, both the compositions showed almost similar microstructure consisting of smaller primary mullite aggregates $(<1 \mu \mathrm{m})$ and elongated secondary mullite crystals $(>1 \mu \mathrm{m})$ embedded in the glassy matrix. Quartz grains were mostly dissolved at $1300^{\circ} \mathrm{C}$ in both the cases. Incorporation of flyash in a normal porcelain composition in place of quartz, increases the mullite and glass content and decreases the quartz level at all temperatures of heating $\left(1150-1300^{\circ} \mathrm{C}\right)$. This substitution also increases the flexural strength significantly. Improved microstructure and higher flexural strength at lower temperature by flyash addition in a normal porcelain composition are some of the techno-economic advantages besides its valuable use as a waste material.

\section{Acknowledgements}

The authors would like to thank Prof. N K Mitra, Calcutta University, Kolkata, for his valuable suggestions and encouragement during the course of this work. The authors express their thanks to Mr Asoke Mandal, CGCRI, Kolkata, for SEM studies. The authors also acknowledge the sponsorship of this research work by H\&R Johnson (India) Ltd.

\section{References}

Braganca S R and Bergmann C P 2003 Ceram. Int. 29801 Carty W M and Senapati U 1998 J. Am. Ceram. Soc. 813 Chaudhuri S P 1974 Am. Ceram. Soc. Bull. 53 169, 251

Chen C Y and Tuan W H 2002 J. Am. Ceram. Soc. 851121

Dana K 2003 Utilization of some industrial waste materials in the triaxial composition for the preparation of ceramic tiles, Calcutta University, Kolkata

Ece O I and Nakagawa Z 2002 Ceram. Int. 28131

Hillebrand W F and Lundell G C E 1953 Applied inorganic analysis (New York: John Wiley and Sons) 2nd ed.

Iqbal Y and Lee W E 1999 J. Am. Ceram. Soc. 823584

Iqbal Y and Lee W E 2000 J. Am. Ceram. Soc. 833121

Johnson S M and Pask J A 1982 Am. Ceram. Soc. Bull. 61838

Klein A A 1916-17 Natl. Bur. Std. Tech. Paper 3

Kumar S, Singh K K and Rao P R 2001 J. Mater. Sci. 365917

Lee W E and Rainforth W M 1994 Ceramic microstructures (London, UK: Chapman \& Hall)

Lee W E and Iqbal Y 2001 J. Eur. Ceram. Soc. 212583

Lundin S T 1954 in Trans. of IVth int. ceram. cong., (Florence, Italy: Publ. Org. Comm.) p. 383

Lundin S T 1964 Nat. Bur. Stand. (US) Misc. Publ. 25793

Mattyasovsky L 1957 J. Am. Ceram. Soc. 40299

Metcalfe B L and Sant J H 1975 Trans. Br. Ceram. Soc. 74 193

Palatzky A and Tummler W 1958 Silikattechnik 968

Rado P 1971 Trans. Br. Ceram. Soc. 70131

Schuller K H 1964 Trans. Br. Ceram. Soc. 63103

Schuller K H 1982 J. Edu. Mod. for Mater. Sci. 4537

Weyl D 1959 Ber. Deut. Keram. Ges. 36319

Wiedmann T 1959 Sprech 922 